\title{
Article
}

\section{Regulation, Registration and Social Work: An International Comparison}

\author{
Worsley, Aidan Richard clive, Beddoe, Liz, McLaughlin, Ken and \\ Teater, Barbra \\ Available at http://clok.uclan.ac.uk/31262/ \\ Worsley, Aidan Richard clive ORCID: 0000-0002-3925-3297, Beddoe, Liz, \\ McLaughlin, Ken and Teater, Barbra (2020) Regulation, Registration and Social \\ Work: An International Comparison. The British Journal of Social Work, 50 (2). \\ pp. 308-325. ISSN 0045-3102
}

It is advisable to refer to the publisher's version if you intend to cite from the work. http://dx.doi.org/10.1093/bjsw/bcz152

For more information about UCLan's research in this area go to http://www.uclan.ac.uk/researchgroups/ and search for <name of research Group>.

For information about Research generally at UCLan please go to http://www.uclan.ac.uk/research/

All outputs in CLoK are protected by Intellectual Property Rights law, including Copyright law. Copyright, IPR and Moral Rights for the works on this site are retained by the individual authors and/or other copyright owners. Terms and conditions for use of this material are defined in the policies page.

\section{CLoK}

Central Lancashire online Knowledge www.clok.uclan.ac.uk

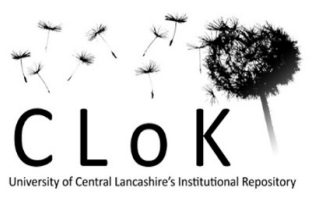




\section{Regulation, Registration and Social Work: an international}

\section{comparison}

${ }^{1 *}$ Aidan Worsley, ${ }^{2}$ Liz Beddoe, ${ }^{3}$ Ken McLaughlin and ${ }^{4}$ Barbra Teater

${ }^{1}$ University of Central Lancashire, School of Social Work, Care and Community, Eden Building, Preston PR1 2HE, UK.

${ }^{2}$ University of Auckland, Faculty of Education \& Social Work, Epsom Campus, 74 Epsom Avenue, Epson, Auckland, New Zealand.

${ }^{3}$ Manchester Metropolitan University, Department of Social Care \& Social Work, Brooks Building, 53 Bonsall Street, Manchester, M15 6GS, UK.

${ }^{4}$ College of Staten Island, City University of New York, Department of Social Work, 2800 Victory Boulevard, Staten Island, New York 10314, US.

*Correspondence to Aidan Worsley, Professor of Social Work, School of Social Work, Care and Community, Eden Building, University of Central Lancashire, Preston PR1 2HE. Email: arcworsley@uclan.ac.uk 


\section{Abstract}

The anticipated change of social work regulator in England from the Health and Care Professions Council to Social Work England in 2019 will herald the third, national regulator in seven years for the social work profession. Social Work England will be a new, bespoke, professionally specific regulator established as a non-departmental public body with a primary objective to protect the public. Looking globally, we can observe different approaches to regulation of the social work profession - and many different stages of the profession's regulatory journey between countries. Using a Comparative Policy Analysis approach and case studies, this article looks more closely at three countries' arrangements and attempts to understand why regulation might take the shape it does in each country. The case studies examine England, the United States (as this has a state approach we focus on New York) and New Zealand, with contributions from qualified social work authors located within each country. We consider that there are three key elements to apply to analysis: definition of role and function, the construction of the public interest and the attitude to risk.

Keywords: Regulation, Social Work, Social Policy, International Social Work, Fitness to Practice 
Introduction

On the $14^{\text {th }}$ January 2016, Nicky Morgan, then UK government Secretary of State for Education, announced plans to remove social work (in England) from the regulatory control of the Health and Care Professions Council (HCPC) and to place it within a profession specific regulatory body (subsequently titled Social Work England), which is due to take on its functions in December 2019. Her statement noted that, 'the new body will have a relentless focus on raising the quality of social work, education, training and practice in both children's and adult's social work' (Department for Education, 2016). With this announcement, social work in England was consigned to experience its third national regulator in seven years. Indeed, at the time of the announcement, the HCPC had been regulating the profession for less than four years. This article begins as an attempt to understand some of the political and conceptual elements of this relatively rapid period of change by placing them in a broader international context. Through the use of case studies within a Comparative Policy Analysis model, we will examine three countries' experience of social work regulation and the journey it has taken to arrive at its current point. In addition to England, the territories chosen include New York in the US, where there is state rather than national regulation of the profession. This is contrasted with New Zealand, where a national debate recently took place about planned legislation around social work regulation. The authors of the case studies, who are social work academics with a strong interest in regulation, examine the narrative journey of the profession within their own country/state towards - or away from regulation. In particular, the structural elements of regulation are discussed, namely protection of title, registration, fitness to practice and education and training. This article acts as a contribution to a relatively small field of analysis about international social work 
regulation by also placing the profession's experience within the broader literature of the growth of regulation across a range of professions and areas of social governance.

This research takes its first steps as an attempt, through Comparative Policy Analysis (CPA), to better understand the nature of the changes in social work regulation policy in England Given the investigative thrust of this research, a strong theoretical model is required to marshal the information gathered - and CPA perhaps affords the most appropriate model. 'Comparison lies at the heart of all policy analysis' (Wolf and Baehler, 2018, p. 420) in that it facilitates an understanding of one's own situation via benchmarking, revealing the impact of key policy actors, sources of potential policy transfer and the political differences that shape them (Radin and Weimer, 2018). Thus, by understanding the situation of others we better understand our own. Methodologically, we have adopted a 'case study' approach, which allows contextually rich, interactive comparison, over time, which is specific to a place but also affords an opportunity to develop extended narratives - albeit constrained by space herein (Wolf and Baehler, 2018). There are, of course, limits to this approach, Marmor (2017) for example describes CPA as 'lacking a common framework' whilst Rabin and Weimar (op. cit.) warn of the dangers of 'naïve transplantation' (insufficiently considered adoption). To address these issues we have focussed more on understanding - and in so doing have benefitted especially from the recruitment of country-specific expertise to develop a broader understanding of each country's situation - again a feature of CPA (Radin and Weimar, 2018). Four key elements will be presented that shape the theoretical approach of this piece, which draws particularly on Marmor's (op.cit.) and Radin and Weimar's (op.cit.) recent work on 'rules' for CPA. First is clarity - of purpose, where we are 
attempting to understand the shape of social work regulations in three different areas (England, New York and New Zealand) to better understand, particularly the recent spate of changes in regulation in England - whilst avoiding the 'muddled language' of, in this case, regulation. The second rule is related to context - and each case study will attempt to contextualise the nature of the (social work) sector as it exists in each country. The third rule relates to definition to ensure comparisons are meaningful through clear definition of approach. Our case studies will examine three key areas: registration (a state sanctioned model of listing 'approved' practitioners), fitness to practice (a model for investigating the behaviour of practitioners against professional standards) and protection of title (arrangements for who can be formally labelled a social worker). Finally, the fourth rule relates to our need to examine country specific constellations of values, politics and institutions that affect our comparative analysis which we will do through our case studies (Marmor, 2017).

Contextually, we are also cognisant of a range of literature around the sociology of professions and note particularly that the twentieth century witnessed a growth in occupations seeking to become professions, a process whereby they sought recognition for their particular form of expertise beyond that of the general public (Elliott, 1972; Malin, 2017). However, it is interesting to note that one review of the existing literature found 'there is only limited empirical evidence as to whether registration does in fact lift the professional standing of social workers or protect consumers from substandard practice' (McCurdy et al., 2018, p.1). 
Whilst the drive for professional regulation was broadly welcomed there have been some criticisms of the rationale for, and operation of, the regulatory authorities for social work. It has been argued that there is an inherent power imbalance, for example, in the proceedings around fitness to practice and there is often a failure to take into account wider structural and organisational failings that can negatively impact a social worker's ability to do their job (Kirkham et al, 2019). However, any attempt at an analysis of the regulatory processes in place for social work is not straightforward due to significant variation in the activities defined as social work, with some countries not including statutory responsibility for individuals, whether children or adults, as being part of a social worker's duties (Hussein, 2011). Given such disagreement over the roles and tasks of social workers from country to country, it should be no surprise that there is also divergence in the way the profession is, or is not, regulated.

Case Study 1: England

\section{Structure}

Social work in England became a regulated profession following the inception of the General Social Care Council (GSCC) in 2001. The GSCC's sister organisations in Scotland, Wales and Northern Ireland (the Scottish Social Services Council, Care Council for Wales (now Social Care Wales) and Northern Ireland Social Care Council) were founded the same time and still currently perform their regulatory functions. Since 1st April 2005, 'social worker' has been a protected title under the Care Standards Act 2000 in England and Wales, with Scotland (September) and Northern Ireland (June) coming on line later that year. Only those registered could use the title or carry out the tasks of a social worker - or face a fine of up to 
£5000. Looking across Europe, Hussein $(2011,2014)$ examined transnational social work recruitment into the UK, its Commonwealth bias and observed the 'very diverse' range of social work roles and qualifications across the European Union.

In 2012, the Health and Care Professions Council assumed responsibility for the 'register' which it maintains for 16 different professions, with 93,206 Social Workers currently registered (in England) amounting to approximately 27\% of the total register (HCPC, 2018) which includes professions such as arts therapists, biomedical scientists, dieticians and speech and language therapists. Graduates of approved courses (at both undergraduate and post-graduate levels) apply to enter the register and a social worker must be registered to actively perform their duties. If a registered professional fails to meet the required professional standard they can be called before a 'Fitness to Practise' hearing where the ultimate sanction could be that professional registration is removed. This is especially pertinent given that all the professions listed above have 'protection of title', meaning that only those on the HCPC's register can call themselves by their respective professional title. Thus, in terms of social work in England, anyone struck off can no longer practice as, or even call themselves, a social worker.

Narrative

With the regulation of social work, England finds itself in a state of transition on a number of fronts. At the time of writing, England is in a form of regulatory interregnum as we await the HCPC replacement and details of any transitional arrangements. The Children and Social 
Work Act 2017 was granted royal assent on the 27th April 2017, creating a new body (Social Work England) which will assume its regulatory functions in 2019. The move from specialist profession to generic sector regulator and back is notable for its relative speed and the profession will have related to three different national regulators in seven years by 2019. Furthermore, within this timeline, The College of Social Work has come and gone. Arriving from recommendations made by the Social Work Task Force, the College was initiated in 2012 and formed as an independent (England focussed) body within a broad professional college model, designed to promote the profession and quality standards of social work within practice and education. By June 2015 its doors had closed ostensibly around funding, never managing to find sufficient membership nor adequately win government confidence, to free itself from reliance on central finance (Community Care, 2016). Nevertheless, others saw this as another move in central control of a profession that was increasingly at the mercy of political interference (Beresford, 2015). The ability to exert such control is arguably linked to, or facilitated by, opportunity borne from the extremely high visibility of national child protection scandals in the UK, attendant constructs of public interest and subsequent policy intervention. The establishment of the GSCC (in 2001) was clearly part of a policy response to the case of Victoria Climbié who died in February 2000 (Laming, 2003) but also a product of the New Labour government which came into power in 1997 and oversaw a marked increase in the regulation of all professions (Haney, 2012). However, as noted above, the GSCC was abolished and all of its powers transferred on August 12012 to the Health Professions Council (HPC) which, in recognition of the expansion of its remit, changed its name to the Health and Care Professions Council (McLaughlin et al., 2007; McLaughlin et al., 2016). This time, the public interest backdrop related to the case of Peter Connelly who had died in August 2007 (Laming, 2009). 
Social work appears to be a highly volatile policy space in England in recent years with a plethora of government initiatives, often led by the Department for Education (DfE) whose UK mandate lies around children's services and education. Many of these infringe on what might be termed the 'regulatory space' of the profession. Thus, at qualifying level we have seen the introduction of new, compressed, work based entry routes, and Teaching Partnerships (Department for Education, 2016a) - a funding stream supporting high academic tariff, Local Authority orientated and led arrangements which have two tiers of criteria (basic and stretch) which form a 'semi-regulatory' requirement in excess of the HCPC Standards for Education and Training (SETs). The HCPC operates a model of generic standards (SETs) that it uses to assess against to approve provision, and similarly Standards of Proficiency which are professionally specific threshold outlines of what a student must 'know, be able to understand and do' by the time they complete their training. The SOPs are designed as 'the threshold standards necessary to protect members of the public'. (HCPC, 2017). Other risk orientated approaches to the control of the regulatory space of social work include the new pilot of the National Assessment and Accreditation Scheme currently being rolled out by the DfE.

With regard to the regulatory management of direct practitioner risk it is interesting to note that Fitness to Practice has become the major business strand for the HCPC. Against an annual income of $£ 31 \mathrm{M}$, the HCPC spends nearly half ( $\mathrm{f} 15 \mathrm{M}$ ) of its income each year on the pursuit of fitness to practice issues, conducting some 1200 public hearings every 12 months (HCPC, 2017a). Furthermore, we can see that despite social workers forming $27 \%$ of the 
whole HCPC register, they account for $51 \%$ of the numbers of fitness to practice cases. In a recent HCPC Fitness to Practice report we find that $1.3 \%$ of the registered social workers are subject to some form of referral but have the greatest volume (59\%) closed at initial investigation (HCPC, 2018).

Case Study 2: USA/ New York

Structure: US

Social work in the United States (US) is regulated by 50 individual states and the District of Columbia (D.C.) through individual state licensing boards. Social work regulation was first established by the state of California in 1945, yet the majority of other states did not initiate or establish regulation for many more years (Bibus and Boutte-Queen, 2011). However, due perhaps to an emerging view that employer oversight was inadequate as a regulatory proxy, by the 1970s all states moved toward regulation and licensure of social workers and by 1992 all states and D.C. established legislation regulating social work (Bibus and Boutte-Queen, 2011). In addition, each of the 50 states and D.C. have developed their own definitions of social work (Hill et al, 2017). One reason for the varied definitions is the extent to which social work in the US covers a wide range of tasks spanning from micro (e.g., work with individuals and families often referred to as "clinical" social work) to macro practice (e.g., work involving leadership, management, community organising, and policy development) (Gitterman, 2014). An examination of the 51 state and D.C. definitions identified more emphasis on micro or clinical practice over macro practice (Hill et al., 2017). Therefore, not only is there a lack of a single definition of social work practice within the US, but also a lack of a consistent, national regulatory body or set of guidelines of the profession of social work 
across the US, which is argued to have implications for solidarity within the profession, public perception of social work, and identification as a social worker (Lightfoot et al, 2016). Due to the state-level regulation in the US, this case study focuses specifically on one state, New York State, as it has one of the highest numbers of employed social workers in the US (Bureau of Labor Statistics, 2018).

Structure: New York State

In New York State (NYS), licensing and professional regulations for social work are guided by Title VIII of the NYS Education Law, the Commissioner's Regulations and Rules of the Board of Regents, and administrative decisions made by the State Education Department. The title of "social worker" on its own is not necessarily a protected title but, rather, the titles associated with social work licensure are protected, which are only granted to individuals who qualify from a graduate social work programme (i.e., Master of Social Work [MSW]). Individuals who qualify with a social work degree at the undergraduate level are not required to obtain a professional social work license; in fact, there is no social work license available for individuals who qualify at this level in NYS. In NYS, the protected titles associated with social work are the two available licenses: licensed master social worker (LMSW), and licensed clinical social worker (LCSW). Only individuals who hold either a LMSW or LCSW may use the relevant titles with LCSWs being able to provide clinical social work or psychotherapy whereas LMSWs can only provide clinical social work under supervision. Although "social work" is not a protected title, in order to practice social work in organisations individuals are required to hold a LMSW or LCSW and must register their 
license with the State Education Department's Office of the Professions. As of January 1, 2019 there were 26,884 LMSWs and 25,254 LCSWs registered in NYS (NYSED, 2019a).

Individuals holding the LMSW and LCSW are obligated to adhere to the state laws and regulations governing the profession and are advised to follow the practice guidelines consisting of values, ethical principles and standards as stipulated by the National Association of Social Workers (NASW) Code of Ethics (NASW, 2017). Allegations of professional misconduct can only be made when the individual violates the state laws and regulations (not when violating professional guidelines), which will result in an investigation of professional misconduct. Boundaries of professional practice and unprofessional conduct in the practice of social work as an LMSW and LCSW is set out in section 7708 of Article 154 of the Education Law and Part 29 (sections 29.1; 29.2; 29.16) of the Rules of the Board of Regents and relate to competence, criminality, and professionalism.

Any person or organisation who has reasonable cause to suspect professional misconduct is to report such violations to the Professional Conduct Officer at the Office of the Professions, NYS Education Department. In serious cases, disciplinary proceedings may involve suspending or revoking a license and removal of the individual from the register of licensed social workers with the State Education Department's Office of the Professions. In 2018, there were 14 summaries of actions on professional misconduct and discipline against social workers (NYSED, 2019b); this number represents $0.03 \%$ of the total 52,138 registered social workers. Of the 14 summaries, six individuals surrendered their license, and the remaining eight were subject to suspension and/or probation with fines ranging from $\$ 500$ - \$2000. 
Narrative

There is clearly a lack of unity in the regulation of social work across the 50 states and D.C. NYS places emphasis on social work practice at an advanced level where licensure is only granted to individuals obtaining a graduate qualifying social work degree (i.e., MSW). The title of social work is not protected, which lessens the credibility of the title among the general public. This leaves unlicensed individuals who are using the title of social worker unprotected and unregulated, which contributes to a lack of unity among the general public as to the role and function of social work. Equally in NYS, registration and professional misconduct rules and investigation procedures are placed alongside other state regulated professions (e.g., physical therapy; architecture; public accounting), which does not provide social work a single platform in which to report, investigate, or inform the public of any professional misconduct cases among social workers. The lack of making the public aware of social work misconduct is further reinforced by allegations or final dispositions rarely (if ever) being reported in the mainstream news; thus, there is no public discourse shaping the regulation of the profession.

National social work associations and organisations are working to bring more solidarity to the social work profession through standardised codes of ethics to guide professional conduct (NASW, 2017), and through standardised regulatory procedures. For example, the Association of Social Work Boards (ASWB) has developed the Model Social Work Practice Act to assist state legislators and social work boards to regulate social work in a more consistent manner whereby the "Model Act establishes standards of minimal social work 
competence, methods of fairly and objectively addressing consumer complaints, and means of removing incompetent and/or unethical practitioners from practice" (ASWB, 2015, p.1). It is interesting to note the absence of 'protection of the public' in this approach, so central in England's structure. But until such models are adopted across the 50 states and D.C., there will continue to be variations in definitions of social work, title protections, requirements for registration, and regulations of the social work profession based on state jurisdiction.

Case Study 3: New Zealand

\section{Structure}

Recent amendments to the New Zealand legislation, passed in March 2019, have provided for mandatory registration and protection of title for social workers. This replaces the former arrangement in which registration by the Social Workers Registration Board under the Social Workers Registration Act 2003 (hereafter SWRA or 'the Act') was voluntary, unless required by employers as in statutory social work, public health services and some agencies providing services to children and young people. A public register is maintained by the Social Workers Registration Board (SWRB), which is a Crown entity, reporting to the parliament through a cabinet minister. To maintain the right to practise, social workers will hold a Practicing Certificate, renewed each year. Eligibility to register requires a recognised New Zealand social work qualification, a four-year Bachelor of Social Work or a two-year Master of Social Work, both of which require minimum days of supervised field education. 
All social workers have to meet a minimum number of hours of Continuing Professional

Development (CPD) and maintain a CPD log which may be audited.

The Social Work Registration Act 2003 established a disciplinary tribunal and in the document 'Procedures for dealing with Complaints and Notifications of Concern' (SWRB, 2017) the policy and procedures for dealing with complaints are set out. Notifications of concern can raise questions about a social worker's conduct, competence or fitness to practice (health/ reputation). Any person can raise a concern and employers are encouraged to involve the SWRB where a registered employee has: been dismissed for any reason; resigned from their employment prior to disciplinary action or full investigation; been the subject of disciplinary action or an investigation; or there are significant health; and /or competence concerns.

Narrative

The registration of social work in New Zealand was introduced in 2003 by the Labour government. Criticism of social work, arising from public alarm about a series of child abuse tragedies, led to legislation to set up limited registration (Connolly and Doolan, 2007). The Social Workers Registration Act was passed in 2003 with widespread support from practitioners and most employers. For a detailed account of the history of this process see Hunt $(2016,2017)$. New Zealand thus followed a pattern found elsewhere- in the United Kingdom, for example where registration occurred at about the same time and in a similar climate (Kirkham et al., 2019). 
The New Zealand Health Practitioners Competence Assurance Act (HPCA) was also passed in 2003 , set up to protect the safety of the public by ensuring that registered health practitioners are fit and competent to practise. The social work legislation was developed with the HPCA in mind, but the non-mandatory nature of social work registration meant that all health social workers were not legally required to be registered at this time, although a ministerial intervention meant that all social workers worked in directly government funded health services were expected to register. The 2007 review made significant recommendations including legislative amendments to the SWRA 'to provide for a comprehensive system of social worker registration through protection of the title" social worker" and by requiring that functions normally performed by social workers cannot be performed by unregistered persons', (SWRB, 2007, p.13) although these recommendations was not acted upon for ten years. At the time of writing amendments to the SWRA have just passed into law (March 2019). The Social Workers Registration Legislation Bill was written to raise the professionalism of social work by increasing the coverage of the regulatory regime; ensuring social workers are competent and fit to practise; and increasing the effectiveness and transparency of the way the SWRA works. The long-awaited changes in the new legislation include the shift to mandatory registration and protection of title.

The path to the amended legislation was not smooth. The Aotearoa New Zealand Association of Social Workers (ANZASW) and other bodies and individuals provided written and oral submissions on an earlier iteration of the amendment Bill, which had been greeted with consternation. In a letter to members, urging them to lobby the Minister, the ANZASW 
summed up a major concern held by many, that as it stands "the Bill will only require practitioners in paid or voluntary roles that are described using the words social worker to be registered and hold a current Annual Practicing Certificate" (ANZASW Submission, April 2018). The source of the concern was the 'Definition of Practicing as a Social Worker' in Section 8 (new clause $6 A A A B$ ). In this section registration was only required if a person is in a position that is described using the words social worker or the person identifies themselves as a social worker, a definition that was feared to overly empower employers to determine whether or not a person is a social worker by manipulating job titles. Professional groups expressed significant concern that the legislation, rather than strengthening the profession would divide into two distinct groups of practitioners: Registered social workers: qualified social workers employed in roles described as social work who would be required to register and accountable to the SWRB, and a second group of unregistered but qualified practitioners, who are employed in a non-social work designated role but who are indeed practicing social work. The final version of the legislation, developed with considerable input by social work professional bodies, has alleviated these concerns and set in motion work to develop a full scope of practice to ensure social work roles and tasks are clearly defined.

Registration, and the qualifications and competencies for practise remains an area of contention in the social work profession in New Zealand. A review of social work education is likely to be initiated in the next twelve months and again is likely to raise many competing views (see Hunt et al, 2019 for the history of regulation of qualifications in New Zealand). Hobbs and Evans (2017), note that "Government is not a passive player in the construction 
of social work identity", noting that government has a role to play in actively targeting "ongoing negative media attention and be seen to be taking action to improve the standards of practice for social workers" (p.21). However, they note despite recent developments, the long-standing reluctance of the New Zealand government to adopt mandatory registration for social workers has undoubtedly had an impact on both public perceptions of social work and social work identity.

Analysis

This article has sought to enhance our understanding of social work regulation through the lens of Comparative Policy Analysis and, specifically, through attention to its four 'rules': an awareness of context, clarity (of purpose), meaningful comparisons through shared definition and sensitivity to the constellations of values, politics and institutions that shape such a policy (Marmor, 2017). Our three case studies have, through their depiction of both structure and narrative across approaches in England, the US and New Zealand presented a firm base of context which affords us an opportunity to help shape our understanding in relation to the remaining three 'rules'.

Clarity and Risk

One element of clarity that appears to be particularly at the forefront of understanding comparative social work regulation is in the differing constructions of risk management which have shaped its purpose, form and actions. Recent years have seen a range of theories and commentaries that examine the management of risk in regulatory function (Gunningham et al, 1998; Majone, 1999). Authors such as Hood et al (2001) lay out the 
development of 'risk regulation regimes', whilst Black (2005), considering financial service regulation, for example, connects the narratives of new public management with risk-based approaches to regulation that perhaps form an attempt to control the uncontrollable by seeking to, 'emphasise homogeneity and commensurability rather than variability and uniqueness, and (are) designed to be a framework for the systematisation and enhanced rationalisation of the regulatory process and, as such, an important tool of management control' (Black, 2005, p.538). The constructed expression of risk management and the 'protection of the public' - is a central tenet and common facet of regulation across a wide variety of professions. Vogel (2012) argues that changing configurations of private and public pressures, particularly in response to public scandals and tragedies, can help explain changing patterns of risk governance. Certainly, in the case of England and New Zealand there are clear links between regulator shifts in social work and cases such as those of Peter Connolly and Victoria Climbié (see for example Stanley and Manthorpe, 2004) - and, by exclusion, perhaps this is one of the reasons we see less volatility in regulation in the US. Hood's (2011) memorable phrase of 'blame prevention re-engineering' summarises how regulatory regimes across a range of public spheres are designed with the intention of covering someone's (or the executive's) back. For social work in particular, it is noticeable that the concept of risk not only has meaning for the central purpose of regulation, but helps shape its operation as a regulator. Rothstein et al. (2013) examine patterns of riskbased governance in Europe across a wide variety of professions and work areas exploring how such risk based approaches are used as a way of 'rationalising the management of the puzzles, conflicts and trade-offs that inevitably constrain governance interventions' (p.216). They continue by arguing strongly that regulation and the management of risk is not simply about public protection - but about the management of risk to central government and the 
avoidance of blame. For them, risk becomes the euphemistic replacement for failure. Thus, when seeking to understand social work regulation structures, its attitude towards (and expression of) risk management strikes us as a key element to clarify.

\section{Definition}

The second rule and strand of understanding is one of definition - and, as first principle, what we mean by 'social work'. Hussein (2011) in a comprehensive study looking at social work regulation across Europe, found 'extreme diversity' in the construction of social work and, concomitantly, the regulatory infrastructure where it existed. A key feature for Hussein was that social work across Europe was located within a wide variety of professional groupings, in some countries being united under one banner but others where social workers were located in a multitude of different professional groupings. We can see this in the situation of New Zealand where the definition of social work - and who controls it - is a key contemporary issue. Less so in England where legislative imperatives are arguably less disputed - but clearly centrally controlled. In a parallel sense we can also see evidence within the US of how the location of social work in different groupings has led to significant differences of public perception, how different definitions of role and function have led to a fragmentation of regulation, but also how qualification to some extent defines the regulated role more than the act. Viewed as either an act, role or qualification, social work clearly takes on many forms across international boundaries. However, from a regulatory perspective, the individual is the one located on any register (as opposed to an employer). In such a situation the control over the definition of the role has an inextricable link with identity and professional strength. Whilst not explicit within the case studies, our central 
use of notions of power are to be found in the understanding of professional power - and specifically the individual social worker, especially in relationship to employer's and central stakeholders' control over their role. One of the issues we have not focussed upon, but wish to note, is that that from our perspective, whilst England appears to be making headway with integrating the service user voice, it is largely missing from the regulation and narratives of social work education in the US (see, for example, Robbins et. al. 2016). The involvement of service users in NZ is also limited with the exception being the involvement and consultation of Māori which is not just desirable but required under the Treaty of Waitangi and SWRA legislation. Thus, the extent to which service users' voice and involvement helps define and shape the regulation and future direction of social work practice across the three case studies is significantly varied- and linked to the role that 'public interest' plays in this policy area.

\section{Constellations and Public Interest}

The third and final rule is concerned with a sensitivity to the values, politics and institutional elements that shape (regulatory) policy and follows directly from our concern with both professional strength and public interest. Looking more broadly across our case studies we have struggled in correctly locating the construction of 'public interest'. Horowitz (1980) was one of the early authors to examine regulation and to what extent it was done in the public interest - or the professions. There is clearly a link between regulation and the occupation's journey to profession as more groups lobby for privileges in their quest for professional status. We can detect, in New Zealand's experience, a claim from the profession for regulation as part of an appeal for greater status. Equally, we could perhaps 
argue that the limited professional status of social work in the US is linked to its limited regulatory control. Adams (2016) broadens this approach and examines how regulation draws its shape from the different interests of a profession, legitimate social governance and the benefit to society more generally. How, she asks, do we differentiate between regulated professions as part of a state system and their own professional gain - or is regulation to benefit the public and society more generally? As central government seizes its role in effective social governance it expands regulation but, in turn, this creates concern over costs and efficiencies - and therefore public interest takes on an economic element. In England, the sheer cost of Fitness to Practice regulation (focusing on a small percentage of the register) ensures the efficient control over those costs is fundamental to delivery of the whole regulatory framework. Adams (2016) further notes the decline in general of professional esteem ('expert advice is suspect') leading to an oppositional relationship between public interest and the profession's interest. Influential state actors, it is argued, listen more to business leaders, economists and consumer pressure groups and are less open to the claims of professional groups. Taking New Zealand as an example (but arguably England, too), our case study suggests there may well be an economic argument currently influencing the definition of social work and its regulation. If employers (or government) are able to dictate what social work 'is' and therefore what will and will not be regulated, this allows the space to develop where hitherto social work tasks are relocated into lower ranking (lower paid?) work roles outside of regulatory oversight. In New York, we see how the broad, multi-professional regulatory architecture hides (almost removes) the social work profession from the public gaze and links to both a range of social work tasks apparently delivered by unregulated professionals, and a far reduced emphasis on protection of the public. 
Conclusion

Within a necessarily brief, Comparative Policy Analysis approach, we have explored three different structures and narratives of social work regulation with a view to better understanding England's and others recent experience - and illuminating elements of a shared understanding about its forms around the world. In doing so we have identified three key indices of risk, definition and public interest linked to our CPA model that can be deployed in future analysis and examination of regulatory shifts and structures. The pervasive narratives of managerialism and risk management appear to be creating an impetus towards a framework and colour of regulatory control around western social work that may not be sympathetic to the complex nature of the professional role. We have seen evidence of how volatile and fluid this particular policy space can be given its susceptibility to publicity - but also, where this is not necessarily a given, what can be lost. The underpinning nature of the relationships between the regulator, the public and the profession is both complex and changing - and subject to their respective interests. Meanwhile, in other countries, regulation is something the profession is still actively pursuing as it takes its journey to cement professional status. Comparison, we have argued, lies at the heart of policy analysis and we would suggest examining closely the experiences of countries at all stages on this road, to take learning about the advantages and disadvantages of different social work regulatory forms. 


\section{$\underline{\text { References }}$}

Adams, T. (2016) Professional self-regulation and the public interest in Canada. Professions and Professionalism, 6(3), pp.1-15

Association of Social Work Boards (ASWB), (2015) Model Social Work Practice Act, available online at https://www.aswb.org/wp-content/uploads/2013/10/Model_law.pdf (accessed 9th December 2018).

Beresford, P. (2015) Closing the College of Social Work is yet another attack on the profession. Guardian $23^{\text {rd }}$ June 2015 , available online at https://www.theguardian.com/social-care-network/2015/jun/23/closing-the-college-ofsocial-work-is-yet-another-attack-on-the-profession (accessed 4th September 2018).

Bibus, A. A., and Boutte-Queen, N. (2011) Regulating Social Work: A Primer on Licensing Practice. Chicago, IL, Lyceum.

Black, J. (2005) The emergence of risk based regulation and the new public risk management in the United Kingdom, Public Law Autumn 2005 (Autumn) pp. 512-548.

Bureau of Labor Statistics. (2018). Occupational employment and wages, May 2017, available online at https://www.bls.gov/oes/2017/may/oes211029.htm (accessed 17th February 2019).

Community Care (2016) Time to put myths about The College of Social Work closure to bed. Community Care July $14^{\text {th }} 2016$, available online at http://www.communitycare.co.uk/2016/07/14/time-put-myths-college-social-work-closurebed/ (accessed $4^{\text {th }}$ September 2018). 
Connolly, M. and Doolan, M. (2007) Lives Cut Short: Child Death by Maltreatment.

Wellington, New Zealand, Dunmore Press.

Department for Education (2016) Nicky Morgan unveils plans to transform children's social work, Press release $14^{\text {th }}$ January 2016, available online at https://www.gov.uk/government/news/nicky-morgan-unveils-plans-to-transform-childrenssocial-work (accessed 15th June 2018).

Department for Education (2016a) Social Work Teaching Partnership Pilots: An Evaluation, Department for Education, London.

Elliott, P. (1972) The Sociology of the Professions (New Perspectives in Sociology), London, Macmillan.

Gitterman, A. (2014) Social Work: A profession in search of its identity, Journal of Social Work Education, 50, pp.599-607.

Gunningham, N., Grabosky, P., and Sinclair, D. (1998) Smart Regulation: Designing Environmental Policy (Oxford socio-legal studies), Oxford, Clarendon Press.

Haney, J. (2012) Regulation in Action, London, Karnac Books.

Health and Care Professions Council (2017) Standards for Education and Training, London, HCPC.

Health and Care Professions Council (2017a) Annual Report and Accounts 2016-17, London, HCPC.

Health and Care Professions Council (2018) Fitness to Practice Annual Report 2017-18, London, HCPC. 
Hill, K., Fogel, S., Plitt Donaldson, L., and Erickson, C. (2017) State definitions of social work practice: implications for our professional identity, Journal of Evidence-Informed Social Work, 14, pp.266-279.

Hobbs, E. K., and Evans, N. (2017) Social work perceptions and identity: how social workers perceive public and professional attitudes towards their vocation and discipline, Aotearoa New Zealand Social Work, 29(4), pp.19-31.

Hood, C., Rothstein, H. and Baldwin, R. (2001) The Government of Risk: Understanding Risk Regulation Regimes, Oxford, Oxford University Press.

Hood, C. (2011) The Blame Game: Spin, Bureaucracy, and Self-preservation in Government, Princeton, Princeton University Press.

Horowitz, I. (1980). "The Economic Foundations of Self-Regulation in the Professions," in Blair, R.D. and Rubin, S. (eds), Regulating the Professions, Lexington, Massachusetts. Hunt, S. (2016) The social work professionalisation project before the 1990s in Aotearoa New Zealand: the dream, Aotearoa New Zealand Social Work, 28(3), pp.15-25.

Hunt, S. (2017) The social work regulation project in Aotearoa New Zealand, Aotearoa New Zealand Social Work, 29(1), pp.53-64.

Hussein, S. (2011) Social Work Qualifications and Regulation in the European Economic Area (EEA), London, General Social Care Council and Skills for Care \& Development.

Hussein, S. (2014) Hierarchical challenges to transnational social workers mobility: the United Kingdom as a destination in an expanding European Union, British Journal of Social Work 44, Supplement 1, pp.i174-i192. 
Kirkham, R., Leigh, J., McLaughlin, K., and Worsley, A. (2019) The procedural fairness limitations of fitness to practise hearings: A case study into social work, Legal Studies, 39(2), pp. 339-357.

Laming, H. (2003) The Victoria Climbié Inquiry, Norwich, TSO.

Laming, L. (2009) The Protection of Children in England: A Progress Report, London, The Stationery Office.

Lightfoot, E., Nienow, M., Moua, K. N. L., Colburn, G. and Petri, A. (2016) Insights on professional identification and licensure from community social workers, Journal of Community Practice, 24, pp.123-146.

McCurdy, S., Sreekumar, S. and Mendes, P. (2018) Is there a case for the registration of social workers in Australia?, International Social Work, Advance Access published $4^{\text {th }}$ April, 2018, doi.org/10.1177/0020872818767496

McLaughlin, K. (2007) Regulation and risk in social work: The General Social Care Council and the Social Care Register in context, British Journal of Social Work, 37(7), pp1263-1277. McLaughlin, K., Leigh, J. and Worsley, A. (2016) The state of regulation in England: from the General Social Care Council to the Health and Care Professions Council, British Journal of Social Work, vol.46, no.4, pp.825-838

Majone, G. (1999) The regulatory state and its legitimacy problems, West European Politics, 22(1), pp.1-24.

Malin, N. (2017) Theoretical frameworks used in studying professions, Social Work \& Social Sciences Review, 19 (1), pp.7-30. 
Marmor, T. R. (2017) Comparative studies and the drawing of policy lessons: describing, explaining, evaluating and predicting, Journal of Comparative Policy Analysis: Research and Practice, 19 (4), pp.313-326.

NASW (2017) Code of Ethics, available online at https://www.socialworkers.org/About/Ethics/Code-of-Ethics/Code-of-Ethics-English (accessed 9th December 2018).

New York State Education Department (NYSED). (2019a). License statistics, available online at: http://www.op.nysed.gov/prof/sw/swcounts.htm (accessed 21st February 2019) New York State Education Department (NYSED). (2019b). Enforcement actions, available online at http://www.op.nysed.gov/opd/rasearch.htm (accessed 21st February 2019).

Radin, B.A. and Weimer, D.L. (2018) Compared to what? The multiple meanings of comparative policy analysis, Journal of Comparative Policy Analysis: Research and Practice, 20 (1), pp.56-71.

Robbins, S.P., Coe Regan, J. R., Williams, J.H., Smyth, N.J., and Marion Bogo, M. (2016) From the Editor-The Future of Social Work Education, Journal of Social Work Education, 52:4, pp. 387-397.

Rothstein, H., Borraz, O., and Huber, M. (2013) Risk and the limits of governance: exploring varied patterns of risk-based governance across Europe, Regulation \& Governance, $7(2)$, pp.215-235.

Social Workers Registration Board (2007) 'Social Workers Registration Act (2003): Review Report -July 2007', Wellington, SWRB.

Stanley, N. and Manthorpe, J. (2004) The Age of the Inquiry, Routledge, London. 
Vogel, D. (2012) The Politics of Precaution: Regulating Health, Safety, and Environmental Risks in Europe and the United States, Princeton University Press, Princeton.

Wolf, A. and Baehler, K.J. (2018) Learning transferable lessons from single cases in comparative policy analysis, Journal of Comparative Policy Analysis, 20 (4), pp.420-434.

END 